\title{
PERANAN PSIKOLOGI TERHADAP PERKEMBANGAN MASYARAKAT PASCA MODERNISASI ${ }^{1}$
}

\author{
Marrang Paranoan
}

\begin{abstract}
Abstrak
Dalam mencapai Kemajuan 6angsa, terdapat hal-hal positif dan negatif, termasukpersoalan psikologis bangsa. Itu se6a6nya peran seorang teolog dituntut untuk memilki dan menguasai ilmu psißologi dalam tugas pelayanannya
\end{abstract}

Pertama tama saya ingin menjelaskan arti kata dari judul tulisan tersebut di atas, agar kita lebih mudah mengertinya:

Peranan, artinya sesuatu yang menjadi bagian dari sesuatu peristiwa yang penting (Kamus Besar Bahasa Indonesia, Purwadarminta, hal. 735, 1987).

Psikologi, terambil kata Yunani psyche dan logos (logi). Psyche artinya jiwa,Logos (logi) artinya ilmu. Jadi psikologi menurut arti kata adalah ilmu jiwa (M. Dalino, Psikologi Pendidikan, hal. 1, 1997).

Psikologi secara epistemologi (ilmu pengetahuan), adalah ilmu pengetahuan yang mempelajari gejala jiwa dalam bentuk pikiran (ratio), perasaan (emosi), kemauan (karya) yang tampak dalam tingkah laku, perbuatan, tindakan, sikap, sifat, watak, karya seseorang atau sekelompok orang secara sistematis, objektif, metodis dan scientific (Pengantar Psikologi, Ny. Marrang Paranoan, hal. 3, 1985).

Masyarakat, adalah kumpulan orang orang yang hidup bersama pada suatu tempat yang diikat oleh aturan tertentu (K.B.I. Purwadarminta, hal. 636, 1987).

Pasca, artinya sesudah (K.B.I. Purwadarminta, hal. 715, 1987).

Modenisasi, terambil dari kata modern artinya yang terbaru (K.B.I. Purwadarminta, hal. $653,1987)$.

Kita semua tahu, bahwa bangsa Indonesia dijajah oleh Belanda selama \pm 300 tahun, sehungga sebagian besar bangsa Indonesia tidak mengenal huruf alias B.H. (Buta Huruf). Mengapa?

Kalau orang Indonesia dipintarkan, maka pasti mereka tidak mau dijajah. Bayangkan selama 300 tahun, orang Indonesia diperbodoh oleh bangsa Belanda sebagai penjajah.

\footnotetext{
${ }^{1}$ Orasi Ilmiah pada Wisuda Sarjana ke-29 dan Dies Natalis ke-71 STT Jaffray Makassar, Agustus 2003.
} 
Pemerintah Belanda selama menjajah Indonesia, menyelenggarakan pendidikan hanya bagi bangsa Belanda, kaum bangsawan, pegawai, pemerintah Belanda yang sangat kecil jumlahnya. Pendidikan diselenggarakan melalui Volkschool (V.S.), Sekolah Rakyat, Hoogere Inlanscheschool (HIS), Midelbareschool (MS), Amtenareschool (AMS) dan lainnya. Muridnya diajarakan bahasa Belanda dan berbagai ilmu pengetahuan. Bagi rakyat jelata didirikan Sekolah Rakyat (SR) 3 tahun, yang diperuntukkan bagi mereka yang akan diangkat sebagai klerk (juru tulis). Kepada mereka diajarakan menulis, berhitung dan ilmu bumi. Tugas klerk ialah mencatat jumlah penduduk, pajak, hasil bumi yang diekspor seperti lada, cengkeh, pala, kopi, damar, dll.

Perang dunia ke-II pecah, yang dimanfaatkan bangsa Indonesia melepaskan diri dari kaum penjajah Belanda.

Soekarno Hatta memproklamirkan kemerdekaan Indonesia tanggal 17 Agustus 1945. Setelah Proklamasi kemerdekaan Indonesia, berubahlah situasi di tanah air. Seluruh bidang kehidupan mengalami perubahan dan perkembangan. Secara khusus perubahan terjadi dalam bidang pendidikan. Disadari bangsa Indonesia bahwa untuk berkembang sejajar dengan bangsa lain di dunia ini, tingkat pendidakan rakyat harus diperbaharui dan dikembangkan. Wajib belajar usia 6 tahun dicanangkan pemerintah. Pemerintah mendirikan berbagai jenis sekolah, mulai dari tingkat SD, SMP, SMU, Sekolah Kejuruan dan Perguruan Tinggi. Sekolah Kejuruan dipersiapkan untuk mendidik tenaga tenaga terampil yang sangat dibutuhkan masyrakata pasca merdeka. Selajutnya disadari pula oleh pemerintah bahwa untuk membangun dan membentuk manusia Indonesia seutuhnya (pembentukan fisik atau jasmani, rohaniah dan mental), maka dibutuhkan pendidikan sejak dini. Mulailah Taman Kanak-kanak (TK) didirikan di seluruh Indonesia. Kesehatan rakyat sangat diperhatikan, sehingga pemerintah merancang 4 sehat 5 sempurna: "dalam tubuh yang sehat terdapat jiwa yang sehat". Sekolah swasta pun terus berkembang dalam berbagai jenis, sehingga setiap orang bebas memilih jurusan dan bidang yang disukainya.

Akibatnya, perkembangan pendidikan yang sangat pesat membawa dampak modernisasi dalam segala bidang kehidupan seperti, dalam bidang politik, ekonomi, pertanian, peternakan, perusahaan, kesehatan sosial budaya, agama kesenian, keamanan dan ketertiban. Dampak modernisasi menimbulkan dampak positif dan dampak negatif. Dampak positif dari modenisasi membawa perubahan dalam cara berpiki, cara meningkatkan taraf hidup berwawasan luas, mengetahui hak dan kewajiban, cara berkomunikasi, pokoknya mampu beripteks. Disamping dampak positif, muncul pula dampak negatif bagi sebagian besar penduduk Indonesia, karena tak dapat bersaing 
dengan warga masyarakat lainnya. Tampak jelas perbedaan yang menyolok antara yang kaya dan yang miskin. Yang kaya makin kaya dan yang miskin makin menderita. Persaingan yang sangat menyolok dalam masyarakat, menyebabkan pengangguran baik sarjana apalagi bagi tamatan SD, SMP, SMU, bahkan Sekolah Kejuruan. Dampak pengangguran tidak hanya bersifat individual (pribadi), tetapi lebih mengarah ke tindakan yang bersifat psiko-sosio-kriminalitas seperti mencuri, merampok, menjambret, memperkosa, membunuh, bunuh diri, berjudi, bahkan di kalangan pemerintah sendiri terjadi demoralisasi seperti korupsi besar-besaran, prostitusi, dan lainnya.

Dampak pengangguran seperti yang disebutkan di atas, membawa dampak psikologis yang sangat berat bagi individu yang mengalaminya, dampak psikologis dapat bersifat :

1. Frustasi, adalah seorang yang merasa kecewa karena tidak mencapai apa yang dingininya.

2. Stress, adalah seseorang yang sudah frustasi belum dapat mengatasi masalah yang pertama, muncul pula masalah baru.

3. Depresi, adalah seseorang yang masih stress tapi belum dapat memecahkan masalah lama, muncul pula masalah baru, sehingga kepribadiannya terganggu dan mengalami pusing, sakit kepala, maag, darah tinggi, darah rendah, susah tidur, dan menjadi perenung atau penghayal.

4. Neurosa, adalah seseorang penderita depresi yang mengarah ke gangguan syaraf. Penderita ini harus diobati oleh Neurolog (Ahli Syraf).

5. Psikosa, adalah sesorang penderita neurosa yang sudah lupa diri, tidak tau malu, alias gila, harus dirawat oleh psychiater, dokter jiwa.

Penderitaan tersebut di atas dapat mengganggu dirinya, keluarganya, dan masyrakat. Jadi merusak kehidupan bersama.

Pasca modernisasi membawa tiap individu Indonesia ke arah kekbebasan pribadi, kebebasan intelektual, kebebasan sosial bahkan kebeasan moral. Akibatnya, rezim SoehartoHabibie diturunkan dari takhta Kepresidenan dan digantikan oleh Rezim Reformasi yang dinahkodai oleh "Presiden Gus Dur". Tetapi sayang sekali, pemerintahan Presiden Gus Dur hanya seumur jagung. Gus Dur digantikan oleh Megawati-Hamzah Haz, dan sekarang telah ada presiden baru. Rakyat Indonesia berharap melaui pemerintahan Presiden Megawati Soekarno Putri dan Wakjil Presiden Hamzah Haz, rakyat Indonesia akan menikmati kehidupan yang aman, damai, sejahtera lahir batin. Tetapi yang adalah sebaliknya, rakyat semakin gelisah. Gelisah adalah suatu perasaan tidak tentram, khawatir, takut, cemas. Kegelisahaan yang berkepanjangan, dapat menghilangkan kemampuan mencapai rasa bahagia (Ilmu Budaya Dasar, M. Munandar S. hal. 82, 1987). 
Tragedi dunia modern dan dunia globalisasi menyebutkan kebutuhan hidup meningkat, terjadi sifat individualistis dan egoistis yang menonjol, keadaan dan situasi semakin krusial, terjadi persaingan berat antara sumber daya manusia yang berkualitas. Masyrakat lebih digelisahkan oleh situasi politik dan menimbulkan dampak teroris, pemboman di kota-kota besar, kerusuhan antar etnis, demonstrasi yang berkepanjangan, pengedaran obat-obat terlarang (Narkoba) yang makin merajalela, kebutuhan hidup primer tidak terjangkau oleh rakyat, biaya pendidikan sangat mahal membuat rakyat Indonesia makin gelisah, terpuruk dan putus asa. Terpaksa sebagian besar rakyat Indonesia, baik sarjana maupun bukan sarjana melamar menjadi T.K.I. (Tenaga Kerja Indonesia), yang menimbulkan masalah besar bagi dirinya sendiri dan bagi pemerintah.

Dari sejumlah masalah yang telah diuraikan di atas, muncul pertanyaan: Apakah peran, fungsi, tugas Sarjana Teologi baik konsentrasi teologi dan Sarjana Pendidikan Agama Kristen sebagai output Lembaga Perguruan Tinggi STT Jaffray Makassar, dalam membantu pemerintah mengatasi masalah yang dialami oleh rakyat Indonesia.

STT Jaffray Makassar menyusun kurikulum yang memuat sejumlah mata kuliah untuk memperlengkapi sarjan output STT Jaffray, antara lain Psikologi dan Psikologi Pendidikan. Tujuan mata kuliah ini ialah mempelajari dan memahami faktor kejiwaan seseorang atau sekelompok orang, agar dapat membantunya dan memotivasinya untuk mengatasi masalah yang diderita oleh orang tersebut.

Pengalaman psikologi yang telah dipelajari oleh Sarjana STT Jaffray, dapat diterapkan dalam kehidupan berjemaat. Para Pendeta dan Dosen atau Guru Agama harus memahami dan menganalisa kehidupan jemaat yang digembalakannya. Psikologi dapat digunakan oleh para pendeta untuk memahami akal, pikiran, perasaan dan kemauan anggota jemaat, melalui pengamatannya yang jeli. Faktor-faktor apa saja yang mempengaruhi kehidupan anggota jemaat yang menimbulkan kegelisahan dan ketentraman hidup. Para Pendeta dan Guru Agama harus mempelajari masalah jemaat secara serius, mengerti, mengetahui, memahami dan mendalami, serta mereka wajib memberikan guidance and counseling dan bimbingan pastoral kepada warga jemaat, agar tidak terjatuh ke dalam masalah psikologis seperti telah dijelaskan. Para Pendeta, Guru Agama wajib membantu dan memotivasi anggota jemaat menyelesaikan masalahnya dan sekaligus menemukan cara pemecahannya.

Disadari, bahwa alangkah sukarnya mencampuri urusan pribadi seseorang atau sekelompok orang (anggota jemaat). Diperlukan kepercayaan diri (PD) dan kepercayaan klien (penderita) untuk melaksanakan tugas ini. Tetapi sebagai seorang pengikut Kristus yang telah berjanji melaksanakan pelayanan firman terhadap sesama manusia, baik yang 
bermasalah, yang miskin, yang putus asa, yang tertindas dan yang lainnya, maka para Pendeta atau Gembala Sidang harus melaksanakan tugas pelayanan dengan iman dan kasih.

Tiap orang telah memiliki sejumlah potensi, bakat, karunia, kemampuan yang melekat pada dirinya masing-masing, hanya saja ada yang menyadarinya dan ada yang tidak menyadarinya. Karunia itu perlu dikembangkan, apabila ingin mencapai sukses. Kiat-kiat kesuksesan antara lain:

1. Setiap orang harus mempunyai tujuan yang jelas.

2. Setiap orang harus percaya diri (PD).

3. Setiap orang harus memiliki disiplin pribadi (DP).

4. Setiap orang harus memiliki rasa ingin tahu yang dalam.

5. Setiap orang harus belajar seumur hidup (long life education).

6. Setiap orang harus menjalin hubungan yang akrab dan harmonis dengan orang-orang pintar yang kreatif dan inovatis dalam banyak hal.

7. Setiap orang harus mempunyai tingkat pemahaman yang tinggi dan dalam.

8. Setiap orang harus mampu mengendalikan diri (tidak cepat emosi).

9. Setiap orang dapat meraih tujuan yang pasti dengan menggunakan teknologi, informasi, dan ketrampilan.

10. Setiap orang Kristen harus memahami arti Ora et Labora.

Tiap orang telah memiliki sejumlah potensi, bakat, karunia, kemampuan yang melekat pada dirinya masing-masing.

Tuhan memberkati kita sekalian. Amin.

\section{Endnotes:}

${ }^{1}$ Tulisan ini pernah disampaikan dalam orasi Ilmiah pada Wisuda Sarjana ke-29 dan Dies Natalis ke-71 STT Jaffray Makassar, Agustus 2003. 